\title{
The Effect of Flipped Learing Model On EFL Learners' Academic Achievement, Self-Esteem and Self-Confidence
}

\author{
Hojjat Namdaran, namdaranh @ yahoo.com, Imam Reza International University, \\ Mashhad, Iran \\ Omid Akbari, omidakbari777@yahoo.com, Imam Reza International University, \\ Mashhad, Iran
}

\begin{abstract}
The aim of the study is to examine the effect of flipped learning model on EFL learners' academic achievement, self-esteem and selfconfidence. This is a quantitative qualitative study in which a mixed methods design is used for data collection procedure. The study sample includes two groups of intermediate English students who study in foreign language institutions. They are selected by purposive sampling method. This method of sampling allows the researcher to select students with two years of learning experience. In this study, the independent variable of the research is flipped learning model, as opposed to traditional learning approach, while the dependent variables are student' $s$ academic achievement, self-esteem, and self-confidence. One sample pre-test and post-test design is used to collect quantitative data on academic achievement, self-esteem and self-confidence. In order to collect qualitative data, a semi-structured interview is administered to reveal the general attitudes of the students towards the benefits, difficulties and the solutions of the flipped classroom. The results indicate that flipped learning model has significant effect on EFL learners' academic achievement, selfesteem and self-confidence. The researcher concludes that learners with high self-confidence and self-esteem will have a greater academic achievement, and flipped classroom can enhance language learning.
\end{abstract}

\section{INTRODUCTION}

Development is closely aligned with education. Thus, education encompasses an important role within the development of each individual within the society. In other words, development is a method of social amendment, not merely a set of policies and programs instituted for some specific results. It is extremely important not only for individuals, but also for the society. We educate students to feel confident about their learning abilities. This is a well-established education system which enables students to apply their knowledge in everyday life confidently (Rahimi, 2009).

In learning process, students may try as hard as they can, but they cannot be succeeded due to a learning difficulty. This is not fault of their own, but in most cases, they are even labeled as troublemakers in educational context. Mostly, this is a symptom of their feelings of inadequacy at school and a lack of self-confidence. Self-confidence can have a noticeable effect on academic performance. Low self-confidence can reduce the student' s desire to learn, their ability to focus, and their willingness to take risks. On the other hand, positive self-confidence is

158 | IJET $\mid$ Volume. 10, Issue 2. December 2021

Copyright 2021 Hojjat Namdaran, and Omid Akbari are licensed under Creative Commons Atrribution-ShareAlike 4.0 International License. 
one of the main constructs of learning success; it provides a firm foundation of learning (Moore, 2019).

The flipped classroom as a model of blended learning by its various names originates from the use of recorded lectures in 2006 by Jonathan Bergmann and Aaron Sams, high school chemistry teachers from Colorado. In flipped learning model, electronic tools are to deliver the lectures outside the class, and to free up the class time for practical application activities and former homework assignments (Educause, 2012). There are other optional components that can optimize this structure and can provide enhanced learning opportunities to students. In other words, teachers have taken numerous paths to teaching with the flip because the learning context and purposes dictate which features are most beneficial (Bull, Fester, \& Kjellerstrom, 2012).

The focus of class time is changed in the flipped classroom by emphasizing on the learner and learning, thereby leads to more class time dedicated to communication (Bergmann \& Sams, 2012). In its simplest form, teaching is done at home through teacher-made videos prior to the class and homework is now done inside the classroom (Witten, 2013).

The main purpose of technology in flipped classrooms is devoting more class time to practical exchanges in L2 in EFL context. This extra time could allow students to increase their agency degrees and the ability to achieve deeper cognitive work levels. Based on the cognitive load theory (Sweller, 1988), flipped learning can work well in language classes if the students are provided with the opportunities to do the lower level of cognitive load (receiving information and comprehending them) prior to the class and focus on higher levels of cognitive load (application, analysis, synthesis, or evaluation) inside the class through hands-on activities (Sweller, 1988).

In a flipped learning instruction, learners are accountable for their own learning. This means that they are supposed to be able to support themselves and engage in learning with their peers. In addition, learners are expected by themselves to explore the content in greater depth. Based on the provided learning opportunities, they should be able to improve higher order thinking capacity. In addition, learners are actively engaged in the advancement of knowledge through enhanced opportunities to participate in a constructive learning environment.

The role of teachers is usually altered from sage on the stage to guide on the side during flipped classroom time. The teachers must also be informed about the relevant subject matter and also be able to acquire that knowledge from of learner. Since the flipped learning method offers guidance beyond class time, teachers have more time to work with all students and they can effectively serve as facilitators, coaches, mentors or advisors to support students inside the classroom. Teachers will have more opportunities to provide input on the progress of learning for each learner and to help explain certain fallacies about learning at their own pace. The teacher's other important task is to pick the content, authentic materials and build the content video for learners since videos are the key tools for flipped instruction in the classroom. Moreover, teachers need to create an alternative test for learners to evoke and demonstrate their learning knowledge.

Videos and genuine materials provide commonly used materials in flipped learning classrooms. They are the main materials comprising the content and clear instructions that are flipped from the lecture-led classroom. In this scenario, videos are a fantastic learning tool for learners to help them learn outside the classroom at their own pace. On the other hand, genuine resources such as news stories, ads, movies, songs, television shows, journals, magazines, etc can be useful and valuable learning materials for both in-class and out-class activities in a flipped

160 | IJET $\mid$ Volume. 10, Issue 2. December 2021

Copyright 2021 Hojjat Namdaran, and Omid Akbari are licensed under Creative Commons Atrribution-ShareAlike 4.0 International License. 
learning model (Bergmann \& Sams, 2012; Khan, 2012; Driscoll \& Petty, 2013; Pacansky-Brock, 2013).

The advantages of using flipped learning model are efficient use of class time (Cole \& Kritzer, 2009), more active learning opportunities for students (Gannod, Berg \& Helmick, 2008), increased one-on-one interaction between student and teacher (Lage, Platt, \& Treglia, 2000), student responsibility for learning (Overmyer, 2012), and addressing multiple learning styles (Gallagher, 2009; Gannod, et al., 2008).

Students' positive self-esteem is one of the ways to achieve academic achievement success. The students' ability to learn and to behave in a class is highly in correlation with their level of self-esteem. Self-esteem also seems to affect motivation. While not all students with low self- esteem will do poorly in school, there is research that shows low self-esteem can lead to less academic success (Daniel \& King, 1997). It is important to investigate whether self-esteem is effective in learning and behavior or not. It is also important to find a way, or ways, to raise selfesteem and to also motivate learning.

On the decline of self-esteem, the students' attitudes and behaviors will change in a classroom. Students with low self-esteem are tagged as 'bad student' or 'class-clown' in the classroom, although it doesn't indicate that these students are not smart and intelligent as much as their peers. Learning is significantly in correlation with student' s self-esteem. Students with higher self-esteem tend to have a salient role in their own education and they are in the charge of their own learning in contrast to students with lower self-esteem which means higher self-esteem contributes to more participation in the class (Phillips, Smith, Modaff, 2004). Students who are enrolled in the class have a higher rate of achievement than those who don't (Turner \& Patrick, 2004). Along with other variables, positive views about themselves are more likely to engage more in class than those with a negative opinion of themselves (Phillips, et al., 2004).

There is an immediate relationship between learners' confidence and their behavior in speaking a second/foreign language which has been confirmed by many previous studies. For example, Lai (1994) attempted to identify Hong Kong secondary students' level of confidence in using English and the elements initiating different levels of confidence in classroom participation. The results revealed that the most of the participants lacked a sense of selfconfidence in their abilities and capabilities when they intended to communicate with others by means of using English. The learners' reluctance to use a foreign language for the purpose of communication is highly correlated with their level of confidence. This means that affective factors including motivation, personality, intergroup climate, and self-confidence contributes to learners' overall self-confidence in using a foreign language for the purpose of communication which is the most important role of every spoken language (MacIntyre, Noels \& Clement, 1997).

Dulay, et. al. defined self-confidence as a soft skill which plays a vital role in optimizing someone's hard skills. Academic skills of an individul won't be useful if he/she is not confident enough. This means that he/she doesn't have a good self-confidence. Almost all the previous studies indicate that self-confidence is very much linked to the learning of a second language. Researchers found that lower levels of anxiety and a willingness to be outgoing were related to accomplish L2 learning (Dulay, Burn \& Krashern, 1982). This means that lower level of anxiety would lead to higher level of self-confidence. Learners willing to try new and unexpected experiences are likely to search for circumstances in the new language that require real communication. According to Dulay, et.al. (1982), these people have been observed to use a wider range of forms in the target language than those with 'wait and see' personalities who are at

160 | IJET| Volume. 10, Issue 2. December 2021

Copyright 2021 Hojjat Namdaran, and Omid Akbari are licensed under Creative Commons Atrribution-ShareAlike 4.0 International License. 
the same level of L2 development. Self-confidence, thus, possesses a crucial part in language learning and language development.

The social context model was proposed by clement et.al. (1977) in which self-confidence was considered as the main construct that defines the motivation for learning an L2 in a multicultural context and it will develop along with pleasant interaction with L2 community. Therefore, self-confidence can be a factor determining the learner' s motivation which plays a very important in language learning process (Clement, Gardner \& Smythe, 1977).

Some experts (Clement, 1986; Clement \& Kruidenier, 1985) concluded that the more confident the learners are the greater communicative competence they will achieve and the easier they adapt to the natural environment. According to Xu (2011), those experts have not touched the nature of interaction between the individual learners and their social context of learning as well as the effect of those on shaping their confidence. This will highlight the role of social context in development of self-confidence in learning a second language.

Self-confidence is a trait of an individual (a self-construct) that helps an individual to have a positive or rational perception of themselves or circumstances in which they are (Sieler, 1998). This refers to an individual's expectation of his or her ability to accomplish a goal in a given situation, which can be an important factor in ensuring that the capacity of an individual is achieved (Stevens, 2005). In other words, people with a high degree of confidence in themselves have a reasonable perception of themselves and their abilities make them more ambitious in their attempts to learn a second language, in particular.

self-confidence is constituted by self-esteem and self-efficacy altogether. This means that self-confidence is a cover term and it is all inclusive. Self-esteem can be defined as a general feeling of self-worth or self-value. That is, an individual with low level of self-esteem believes that he or she is worthless or inadequate while an individual with high level of self-esteem believes otherwise (Neil, 2005).

The problem is stated as the effect of flipped learning model of blended learning on EFL learners' academic achievement, self-esteem and self-confidence. Then, to solve the students' learning problems posed by their different needs as the result of their different learning styles, flipped classrooms could be implemented to facilitate students with different stages of learning and to engage students more actively in learning process. Flipped classroom serves the principles of personalized-differentiated learning, student-centered instruction, and constructivism (Jenkins, 2016). It is personalized due to the fact that every individual student views/reviews material and learns at their own pace and according to their own needs (Basal, 2015; Egbert, Herman, \& Lee, 2015; Muldrow, 2013).

The core of study focuses on the behavior of the learner in teaching-learning situation influenced by several psychological factors, such as value one assigns to self which is called Self-Esteem. As mentioned above, flipped learning model is a personalized approach in which students have been given the chance to review class materials in the time and place that works best for their own needs. Therefore, need analysis of learners will not be ignored in a flipped learning model.

This study is concerned to examine the following research questions:

1. Does flipped learning model have any significant effect on EFL learners academic achievement?

160 | IJET $\mid$ Volume. 10, Issue 2. December 2021

Copyright 2021 Hojjat Namdaran, and Omid Akbari are licensed under Creative Commons Atrribution-ShareAlike 4.0 International License. 
2. Does flipped learning model have any significant effect on EFL learners self-confidence?

3. Does flipped learning model have any significant effect on EFL learners self-esteem?

4. Does high level of self-confidence and self-esteem can affect EFL learners academic achievement?

\section{METHOD}

In this study, a mixed methods design is used to show the effect of flipped learning model of blended learning on EFL students academic achievement, self-esteem and self-confidence. The independent variable of the research is flipped learning model, as opposed to traditional learning approach, while the dependent variables are students academic achievement, self-esteem, and self-confidence.

To collect quantitative data, of the experimental models, one sample pre-test and post-test design is used. We can conduct pre-tests on academic achievement, and both self-confidence and self-esteem before the treatment (all the pre-tests can be done on one day). Then, the post-tests will follow up at the end. As for the qualitative data, a semi-structured interview was developed by the researcher about learners impressions and perceptions on their experiences in the flipped learning model, and the dairies are kept by the participants in the process of the study. The participants also reported their satisfaction with the target teaching method used in the classroom and their feelings of self-confidence and self-esteem in learning the new materials.

The study included two groups of participants. First group is the experimental group who is taught using flipped learning model, and the second is the control group who is taught in a traditional learning environment. In this study, purposive sampling technique, one of the nonrandom sampling techniques, is used. 26 students ( 20 male, 6 female) formed experimental group and 28 students ( 21 male, 7 female) formed the control group. This method of sampling allowed the use of cases with two years of language learning experience. And their proficiency level is intermediate. They are English learners in foreign language institutes who can work with computers and they have access to internet. All the participants were asked to attend all the treatment sessions.

The following instruments are used in this study:

An achievement test or academic success test was administered to measure how much knowledge or skill learners have achieved in a specific set of time. The content was delivered through video lectures before the class time. The test was developed by a group of experts (a group of experienced teachers and test-makers) that its reliability and validity has been checked before the implementation. The test was given to the learners at the end of their course.

In order to assess the students level of self-confidence, the questionnaire about selfconfidence (especially academic self-confidence) was given to the students. The questionnaire was developed on the basis of the previous literature. For this purpose, FLCAS (Horwitz, 1986) was adapted to be used in order to measure students self-confidence. It consisted of 10 statements about self-confidence, and learners were asked to indicate their level of agreement or disagreement with each statement. The responses were scored on a five-point Likert scale response format, ranging from Strongly disagree to strongly agree. On this questionnaire, a high

160 | IJET| Volume. 10, Issue 2. December 2021

Copyright 2021 Hojjat Namdaran, and Omid Akbari are licensed under Creative Commons Atrribution-ShareAlike 4.0 International License. 
score reflected a high level of self-confidence, whereas a low score indicated a low level of selfconfidence.

The FLCAS has been rigorously validated for internal reliability, test-retest reliability, and construct validity (Horwitz, 1991; Horwitz et al., 1986). Reliability of the scores obtained from the instrument based on the data collected from 108 respondents was quite high with Cronbachs alpha of .93 (Horwitz, 1986). In addition, test-retest reliability carried out with a sample of 78 participants over a period of eight weeks was ascertained to be $r=.83(p<.01)$ (Horwitz, 1991).

The Rosenberg self-esteem scale is a ten item Likert scale which measures self-esteem with items answered on a four point scale, ranging from strongly agree to strongly disagree. The original sample for which the scale was developed consisted of 5,024 High School Juniors and seniors from 10 randomly selected schools in New York State (Rosenberg, 1989). The internal consistency for the RSE range from 0.77 to 0.88 . The test-reset reliability for the RSE range from 0.82 to 0.85 .

A semi-structured intervies was administered to reveal the general attitudes of the students towards the benefits, difficulties and the solutions of the flipped classroom. The validity of the interview questions is also checked by the experts.

This is a quantitative qualitative study. Quantitative data was analyzed statistically by using the SPSS program (Statistical Package for the Social Science) and descriptive analyses (frequency, percentage, means, and standard deviation) was run. The qualitative report was used and employed for analyzing the interview questions.

\section{RESULT}

In order to examine how flipped learning model influenced the academic achievement of EFL learners the pretest and posttest scores of the experimental group of flipped learning model and the control group were compared. The results are shown in the following tables.

Table

Descriptive statistics for academic achievement pretest and posttest scores

\begin{tabular}{|l|l|l|l|}
\hline & $\mathrm{N}$ & Mean & Std. Deviation \\
\hline Experimental group pretest & 26 & 85.3173 & 10.70690 \\
\hline Control group pretest & 28 & 75.9643 & 14.59891 \\
\hline Valid N (listwise) & 26 & & \\
\hline Experimental group posttest & 26 & 91.3365 & 6.67343 \\
\hline Control group posttest & 28 & 85.8482 & 11.15637 \\
\hline Valid N (listwise) & 26 & & \\
\hline
\end{tabular}

The mean score for the flipped learning model group was 85.31 on a one-hundred-point

160 | IJET| Volume. 10, Issue 2. December 2021

Copyright 2021 Hojjat Namdaran, and Omid Akbari are licensed under Creative Commons Atrribution-ShareAlike 4.0 International License. 
scales and the standard deviation was 10.7. Moreover, the mean score of the control group was 75.96 and the standard deviation was 14.5. The results show that the control groups mean score is slightly lower than that of the flipped learning model group and the standard deviation statistic shows that the control group is a little more heterogeneous than the flipped model.

The mean score for FLM group was 91.33 on a one-hundred-point scale and the standard deviation was 6.67. Moreover, the mean score of the control group on the same test was 85.84 and the standard deviation was 11.15. The results show that the control groups mean score is lower than that of the experimental group and the standard deviation statistic shows that the control group is less heterogeneous than the experimental group. Furthermore, in order to analyze the test scores inferentially, the normality of the distribution should be tested.

Table

the Results of $K-S$ Test

\begin{tabular}{|l|l|l|l|}
\hline & statistic & df & Sig. \\
\hline Experimental group pretest & .134 & 26 & $.200 *$ \\
\hline Control group pretest & .148 & 26 & .146 \\
\hline Experimental group posttest & .122 & 26 & $.200 *$ \\
\hline Control group posttest & .148 & 26 & .147 \\
\hline
\end{tabular}

In order to check the normality of distribution of the pretest and posttest scores for the experimental and control groups, the Kolmogorov-Smirnov test was employed for both sets of scores. This test is used to check whether the distribution deviates from a comparable normal distribution. If the $\mathrm{p}$-value is non-significant $(\mathrm{P}>.05)$, we can say that the distribution of a sample is not significantly different from a normal distribution, therefore it is normal. If the $p$-value is significant $(\mathrm{p}<.05)$, it implies that the distribution is not normal. Table 3 presents the results of the Kolmogorov-Smirnov test. As it can be seen, the obtained Sig. value for all scores is higher than .05 . Therefore, it can be safely concluded that the data is normally distributed.

In order to compare the results of pretest and posttest scores of the experimental and the control groups, an independent-samples t-test was carried out.

Table

Independent Samples Test displaying the results of pre-test and post-test on academic achievement

\begin{tabular}{|c|c|c|c|c|c|}
\hline & $t$ & $d f$ & $\begin{array}{l}\text { Sig. } \\
\text { tailed) }\end{array}$ & \begin{tabular}{l|l}
$2-$ & $\begin{array}{l}\text { Mean } \\
\text { difference }\end{array}$ \\
\end{tabular} & $\begin{array}{l}\text { Std. error } \\
\text { difference }\end{array}$ \\
\hline pretest & .708 & 52 & .482 & 2.19437 & 3.09942 \\
\hline posttest & 2.667 & 52 & .010 & 9.35302 & 3.50666 \\
\hline
\end{tabular}

160 | IJET $\mid$ Volume. 10, Issue 2. December 2021

Copyright 2021 Hojjat Namdaran, and Omid Akbari are licensed under Creative Commons Atrribution-ShareAlike 4.0 International License. 
Independent Samples Test displaying the results of pre-test and post-test on self-confidence

\begin{tabular}{|l|l|l|l|l|l|}
\hline & $t$ & $d f$ & $\begin{array}{l}\text { Sig. } \\
\text { tailed })\end{array}$ & $\left(2-\begin{array}{l}\text { Mean } \\
\text { difference }\end{array}\right.$ & $\begin{array}{l}\text { Std. error } \\
\text { difference }\end{array}$ \\
\hline pretest & 1.413 & 52 & .164 & 1.40659 & .99551 \\
\hline posttest & 4.076 & 52 & .000 & 3.61264 & .87304 \\
\hline
\end{tabular}

Table

Independent Samples Test displaying the results of pre-test and post-test on self-esteem

\begin{tabular}{|l|l|l|l|l|l|}
\hline & $\mathrm{t}$ & $\mathrm{df}$ & $\begin{array}{l}\text { Sig. } \\
\text { tailed })\end{array}$ & $\begin{array}{l}\text { (2- } \\
\text { pean } \\
\text { difference }\end{array}$ & $\begin{array}{l}\text { Std. error } \\
\text { difference }\end{array}$ \\
\hline pretest & .459 & 52 & .648 & .45330 & .98818 \\
\hline posttest & 5.783 & 52 & .000 & 5.02198 & .86847 \\
\hline
\end{tabular}

As can be seen in table 3, there was a significant difference between the two groups regarding their level of academic achievement $(\mathrm{t}=2.66, \mathrm{p}<.05)$, and the magnitude of the difference in the means was moderate (eta squared $=0.12$ ).

The results in table 4 indicate that there was a high significant difference between two groups regarding their level of self-confidence. The magnitude of the difference in the means was large (eta squared $=.24$ ), with flipped learning model explaining .24 per cent of the variance in self-confidence of learners.

In table 5, it can be seen that there was statistically significant difference between the level of self-esteem of two groups $(\mathrm{t}=5.78, \mathrm{p}<.05)$. The magnitude of the difference in the means was very large (eta squared $=.39$ ), with flipped learning model explaining .39 percent of the variance in self-esteem of learners.

Five subjects were interviewed. The students were asked about the advantages of watching videos related to the content of class. They mentioned the advantages of watching videos before the class time. The primary advantage is that watching videos familiarize the pupils with the subject, vocabulary and stream of teaching within the class. This may result in a wide selection of data which, in turn, will make learners more independent and productive in many levels. Moreover, their readiness before coming to the class will make an interactive classroom. For instance, pupils will be ready to act and interact with other peers in the class and this will enhance group work and communication skills. Consequently, they can make use of class time appropriately and effectively.

During the interview, the students mentioned some differences between the role of the teacher in a flipped classroom and in a traditional instructor-led instruction. Most of them showed that in a traditional classroom, the teacher starts by warm-up, explaining the content, and making the conclusion at the end of the class. This means that the teacher is like a lecturer who explains all the things they should know. In this classroom, the students are passive. However, in a flipped classroom, students have an overview of what is going to be taught in this session so

160 | IJET $\mid$ Volume. 10, Issue 2. December 2021

Copyright 2021 Hojjat Namdaran, and Omid Akbari are licensed under Creative Commons Atrribution-ShareAlike 4.0 International License. 
that they can discuss and interact confidently. Actually the role of the teacher is as a facilitator. The teacher is responsible for guiding the students to find the right direction of learning. However, in a traditional classroom, the teacher should regularly reflect on his/her teaching abilities, and he/she should continue a self-analysis again and again.

The students were asked about the difficulties of using flipped classroom in learning process. The almost mentioned the similar problems during the learning. The students pointed out to the tools and technologies that they needed for flipped classroom. They should have access to internet connection, and also they should have enough general computer skills in order to participate in an online class. The other point mentioned by students is that they should be prepared before flipping the classroom. They should be noticed about the flipped learning environment. What is meant by flipping the classroom and how it can be applied? This can be an important factor in the fulfilment of a successful flipped classroom because FC is a new approach to language teaching, and the most of the students are not familiar with it.

The students offered variety of suggestions for the difficulties and also the problems they face. The primary suggestion was that free access to internet should be provided to students and teachers by the government. Moreover, the teacher should encourage the students to watch the videos before attending the class. Finally, the students suggested that the teacher can train them how to use flipped classroom.

A reliability analysis was carried out on the test scores of learners. Cronbachs alpha showed an acceptable level of reliability (Cronbachs alpha $=.77$ ). About the internal validity, we tried to minimize the threats to internal validity. For this purpose, the participants were noticed that the results of the study will be kept identical. Moreover, the researcher tried to make the instructions of the instruments clear and appropriate for the level of participants. The location of the interviews was taken into consideration. And about the external validity, purposive sampling method was used.

\section{CONCLUSION}

The findings of this study prove that flipping English classes improves learners" academic achievement more than the traditional lecture-based instruction, so employing flipped learning model in foreign language classrooms can be considered as an effective way of instruction for improving English skills of EFL students. Moreover, learners self-confidence and self-esteem can highly be improved by using flipped learning model. This, in turn, can influence the learners academic achievement. This means that they are significantly in correlation with each other. The enhancement of one can determine the enhancement of the other one. In addition, due to the emergence of COVID-19 pandemic, the students perception about virtual learning especially flipped classroom has changed positively. Thus, it can be used as a new approach to language teaching in foreign language classrooms.

\section{REFERENCES}

Basal, A. (2005). THE IMPLEMENTATION OF A FLIPPED CLASSROOM IN FOREIGN LANGUAGE TEACHING. Turkish Online Journal of Distance Education, 16(4).

Bergmann, J., \& Sams, A. (2012). Flip your classroom: Reach every student in every class every day. Virginia: International Society for Technology in Education.

160 | IJET $\mid$ Volume. 10, Issue 2. December 2021

Copyright 2021 Hojjat Namdaran, and Omid Akbari are licensed under Creative Commons Atrribution-ShareAlike 4.0 International License. 
Bull, G., Ferster, B., \& Kjellstrom, W. (2012). Inventing the flipped classroom. Learning \& Leading with Technology, 40(1), 10-11. Retrieved from

http://www.learningandleading-digital.com/learning_leading/201208?pg=12\#pg12

Cabi, E. (2018). The impact of the flipped classroom on students academic achievement. International review of research in open and distributed learning, 19 (3).

Choi, N. (2005). Self-efficacy and self-concept as predictors of college students academic performance. Psychology in the schools, 42(2), 197-205.

Clement, R., Gardner, R. C. and Smythe, P. C. (1977) Motivational variables in second language acquisition: A study of francophones learning English. Canadian Journal of Behavioural Science, 9,123-33.

Clement, R., \& Kruidenier, B. G. (1985). Aptitude, attitude and motivation in second language proficiency: A test of Clement's model. Journal of Language and Social Psychology, 4, 273-291.

Cole, J. E., \& Kritzer, J. B. (2009). Strategies for success: Teaching an online course. Rural Special Education Quarterly, 28(4), 36-40.

Cockrum, T. (2014). Flipping your English class. Routledge.

Daniel, L. G., King, D. A. (1997). Impact of inclusion education on academic achievement, self-esteem and student behavior and parental attitudes. Journal of Educational Research, 91(2).

Driscoll, T. F., \& Petty, K. A. (2013). Student-driven education with Flipped Learning and 20-Time. Practical Applications and Experiences in K-20 Blended Learning Environments, 120.

Dulay, H., Burt M. \& Krashern, S. (1982). Language two. New York: Oxford University.

Educause. (2012). 7 things you should know about flipped classrooms. Retrieved from http://net.educause.edu/ir/library/pdf/ELI7081.pdf.

Egbert, J., Herman, D., \& Lee, H. (2015). Flipped Instruction in English Language Teacher Education: A Design-based Study in a Complex, Open-ended Learning Environment. The Electronic Journal for English as a second language, 19(2).

Gallagher, K. (2009). LOEX Conference Proceedings 2007: From guest lecturer to assignment consultant: Exploring a new role for the teaching librarian. Ypsilanti, MI: Eastern

Michigan University. Retrieved from

http://commons.emich.edu/cgi/viewcontent.cgi?article=1008\&context=loexconf2007

Gannod, G. C., Burge, J. E., \& Helmick, M. T. (2008). Proceedings of the 30th International Conference on Software Engineering: Using the inverted classroom to teach software engineering. New York, NY: ACM.

Gerstein, J. (2011). The flipped classroom: a full picture. User Generated Education, available at: http://usergeneratededucation.wordpress.com/2011/06/13/the-flipped-classroom-model-afullpicture/.

Horwitz, E, K., Horwitz, M. B., \& Cope, J. (1986). Foreign Language Classroom Anxiety. Modern Language Journal, 70, 125-132.

Jenkins, C. (2016). The Advantages and Disadvantages of the Flipped Classroom. http://info.lecturetools.com/blog/bid/59158/The-Advantages-and-Disadvantages-of-the-Flipped-

Classroom. Erişim tarihi, 12 Eylül 2016.

Khan Academy [Internet]. Assessed 15 May 2012. Available from: www.khanacademy.org.

Lage, M. J., Platt, G. J., \& Treglia, M. (2000). Inverting the classroom: A gateway to creating an inclusive learning environment. Journal of Economic Education, 31(1), 30-43.

Lai, C. (1994). Communication failure in the language classroom: An exploration of causes. RELC Journal, 25, 99-129.

160 | IJET $\mid$ Volume. 10, Issue 2. December 2021

Copyright 2021 Hojjat Namdaran, and Omid Akbari are licensed under Creative Commons Atrribution-ShareAlike 4.0 International License. 
Lockwood, R. (2014). Flip it! Strategies for the ESL classroom. Ann Arbor, MI: University of Michigan Press.

MacIntyre, P. D., Noels, K. A., \& Clement, R. (1997). Biases in self-ratings of second language proficiency: The role of language anxiety. Language Learning, 47, 265-287.

Moranski, K., \& Kim, F. (2016). 'Flipping' lessons in a multi - section Spanish course: Implications for assigning explicit grammar instruction outside of the classroom. The Modern Language Journal, 100(4), 830-852.

Muldrow, K. (2013). A New Approach to Language Instruction Flipping the Classroom. The Language Educator, 11, 28-31.

Neill, J. (2005). Definitions of Various Self Constructs: Self-esteem, self-efficacy, self-confidence \& self-concept. Accesed http://wilderdom.com/self/ on June 14, 2009.

Overmyer, J. (2012, September). Flipped classrooms 101. Principal, 46-47.

Pacansky-Brock, M. (2013). Best practices for teaching with emerging technologies. New York, NY: Routledge.

Phillips, J., Smith, B., \& Modaff, L. (2004). Please dont call on me: self-esteem, communication apprehension, and classroom participation. Informally published manuscript, Psychology, Murphy, La Crosse, Wisconsin.

Moore, P. J. (2019). Academic achievement. Educational Psychology, 39(8), 981-983. DOI: $10.1080 / 01443410.2019 .1643971$.

Rahimi, A., Farvardin, M. T. (2009). The relationships between attitude, self-confidence, compensation strategies, teacher evaluation and class evaluation in Iranian university students. Samara AltLinguo E-Journal-Applied Linguistics, 4.

Rosenberg, M. (1965). Society and the adolescent self-image. Princeton, NJ: Princeton University Press.

Sieler, A. (1998). Self-confidence. Accessed at http://www.newfieldaus.com on March 28, 2009.

Stevens, T. G. (2005).Self-confidence. Accessed at http://www.csulb.edu on April 3, 2009.

Sweller, J. (1988). Cognitive load during problem solving: Effects on learning. Cognitive Science, 12(2), 257-285.

Turner, J. C., Patrick, H. (2004). Motivational Influences on Student Participation in Classroom Learning Activities. Teacher College Record, 106(9), 17591785.

Witten, H. (2013). World languages. In J. Bretzman (Ed.), Flipping 2.0: Practical strategies for flipping your class (pp. 265 - 280). New Berlin, WI: The Bretzman Group.

$\mathrm{Xu}, \mathrm{j}$. (2011). Second Language Learners and Their Self-Confidence in Using English: a Social Constructive Perspective. Asian EFL Journal Quarterly, 13(3), 246,271.

160 | IJET| Volume. 10, Issue 2. December 2021

Copyright 2021 Hojjat Namdaran, and Omid Akbari are licensed under Creative Commons Atrribution-ShareAlike 4.0 International License. 